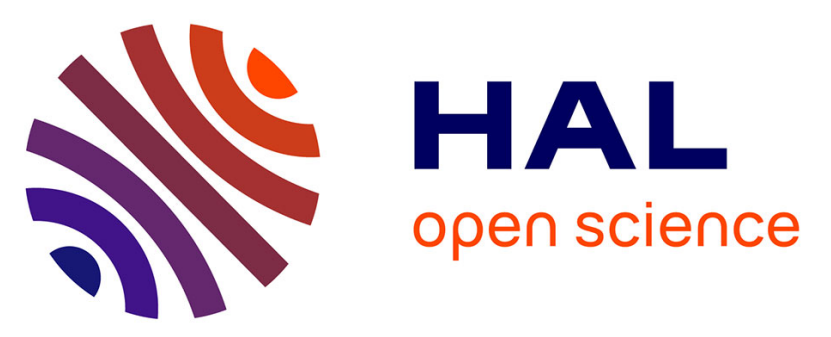

\title{
N-Acetyl-l-cysteine (NAC) inhibit mucin synthesis and pro-inflammatory mediators in alveolar type II epithelial cells infected with influenza virus A and B and with Respiratory Syncytial Virus (RSV)

\author{
Manuel Mata, Esteban Morcillo, Concepcion Gimeno, Julio Cortijo
}

\section{To cite this version:}

Manuel Mata, Esteban Morcillo, Concepcion Gimeno, Julio Cortijo. N-Acetyl-l-cysteine (NAC) inhibit mucin synthesis and pro-inflammatory mediators in alveolar type II epithelial cells infected with influenza virus A and B and with Respiratory Syncytial Virus (RSV). Biochemical Pharmacology, 2011, 82 (5), pp.548. 10.1016/j.bcp.2011.05.014 . hal-00721646

\author{
HAL Id: hal-00721646 \\ https://hal.science/hal-00721646
}

Submitted on 29 Jul 2012

HAL is a multi-disciplinary open access archive for the deposit and dissemination of scientific research documents, whether they are published or not. The documents may come from teaching and research institutions in France or abroad, or from public or private research centers.
L'archive ouverte pluridisciplinaire HAL, est destinée au dépôt et à la diffusion de documents scientifiques de niveau recherche, publiés ou non, émanant des établissements d'enseignement et de recherche français ou étrangers, des laboratoires publics ou privés. 


\section{Accepted Manuscript}

Title: N-Acetyl-1-cysteine (NAC) inhibit mucin synthesis and pro-inflammatory mediators in alveolar type II epithelial cells infected with influenza virus A and B and with Respiratory Syncytial Virus (RSV)

Authors: Manuel Mata, Esteban Morcillo, Concepcion

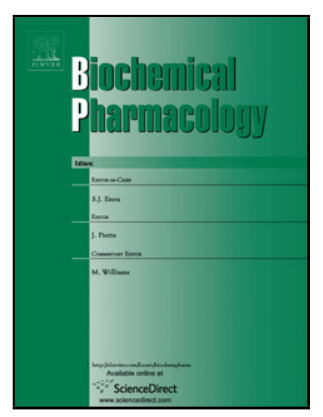

Gimeno, Julio Cortijo

PII:

S0006-2952(11)00327-3

DOI: doi:10.1016/j.bcp.2011.05.014

Reference: BCP 10906

To appear in: $\quad B C P$

Received date: $\quad 20-3-2011$

Revised date: $\quad 15-5-2011$

Accepted date: $\quad$ 16-5-2011

Please cite this article as: Mata M, Morcillo E, Gimeno C, Cortijo J, N-Acetyl-l-cysteine (NAC) inhibit mucin synthesis and pro-inflammatory mediators in alveolar type II epithelial cells infected with influenza virus A and B and with Respiratory Syncytial Virus (RSV), Biochemical Pharmacology (2010), doi:10.1016/j.bcp.2011.05.014

This is a PDF file of an unedited manuscript that has been accepted for publication. As a service to our customers we are providing this early version of the manuscript. The manuscript will undergo copyediting, typesetting, and review of the resulting proof before it is published in its final form. Please note that during the production process errors may be discovered which could affect the content, and all legal disclaimers that apply to the journal pertain. 
N-ACETYL-L-CYSTEINE (NAC) INHIBIT MUCIN SYNTHESIS AND PROINFLAMMATORY MEDIATORS IN ALVEOLAR TYPE II EPITHELIAL CELLS INFECTED WITH INFLUENZA VIRUS A AND B AND WITH RESPIRATORY SYNCYTIAL VIRUS (RSV).

Manuel Mata ${ }^{\text {a,b,c }} *$, Esteban Morcillo ${ }^{b, c}$, Concepcion Gimeno ${ }^{c, d}$ and Julio Cortijo $^{\text {a,b,c }}$.

${ }^{\text {a }}$ research Foundation of the University General Hospital of Valencia, Spain.

${ }^{b}$ Centro de Investigación Biomédica en Red (CIBER) de Enfermedades

Respiratorias, Valencia, Spain.

${ }^{c}$ University of Valencia, Spain.

${ }^{\text {d }}$ University General Hospital of Valencia, Spain.

Corresponding author:

\section{Manuel Mata}

Research Foundation of the University General Hospital of Valencia Avda Tres Cruces n⿳2.

46014. Valencia (Spain).

Telefono: +34961972146

FAX +34961972145

mata manroi@gva.es 


\begin{abstract}
$64 \%$ of Chronic Obstructive Pulmonary Disease (COPD) exacerbations are caused by respiratory infections including influenza (strains A and B) and Respiratory Syncytial Virus (RSV). They affect the airway epithelium increasing inflammatory and apoptosis events through mechanisms involving ROS generation, and induce the release of mucins from epithelial cells that are involved in the deterioration of the patient's health during the course of the disease. The antioxidant NAC has probed useful in the management of COPD reducing symptoms, exacerbations and accelerated lung function decline. It has been shown to inhibit influenza virus replication and to diminish the release of inflammatory and apoptotic mediators during virus infection. The main objective of this study is to analyze the effects of NAC in modulating MUC5AC over-expression and release in an in vitro infection model of alveolar type II A549 cells infected with influenza (strains A and B) and RSV. We have also analyzed virus replication and different pro-inflammatory responses. Our results indicate a significant induction of MUC5AC, IL8, IL6 and TNF-alpha that is strongly inhibited by NAC at the expression and at the release level. It also decreased the intracellular $\mathrm{H}_{2} \mathrm{O}_{2}$ concentration and restored the intracellular total thiol contents. Mechanisms of NAC included inhibition of $\mathrm{NF}-\kappa \mathrm{B}$ translocation to the cellular nucleus and phosphorylation of MAPK p38. NAC also inhibited replication of the three viruses under study. This work supports the use of antioxidants in order to ameliorate the inflammatory effects of different viral infections during COPD exacerbations.
\end{abstract}

Keywords: Influenza, RSV, COPD, NAC, MUC5AC. 


\section{INTRODUCTION}

COPD is a chronic respiratory disease associated with an abnormal inflammatory response of the lungs to noxious particles of gases (mainly cigarette smoke). This leads to chronic bronchitis-bronchiolitis (small airway disease) and/or emphysema that cause an airflow limitation that is not totally reversible [1]. COPD is the fifth leading cause of death worldwide, accounting for more than 2.5 millions deaths every year (WHO world health report 2002). Most of the morbidity associated with this disease is related to episodes of acute deterioration in health that are called exacerbations [2] and are characterized by shortness of breath, cough, increased sputum volume and purulence and other non specific symptoms such as fatigue and malaise. COPD patients experience an average of 2.5 exacerbations per year and its frequency increases with the severity of the disease [3, 4]. Strategies to reduce exacerbations are required because there is a correlation between a faster decline in FEV1 (Forced Expiratory Volume in the first second) and the frequency of exacerbations [5].

Several causative agents have been associated with COPD exacerbations including bacteria, pollutants and respiratory viruses such as RSV and the influenza virus [6]. Nichol and colleagues concluded in 1999 that hospitalization rate in patients who were not vaccinated with influenza was twice the rate in those who were vaccinated [7]. In addition, influenza vaccination was associated with a lower risk of death [7]. The mechanisms used by respiratory viruses to cause exacerbations remain under investigation. Some studies support the role of Reactive Oxygen Intermediates (ROIs) as mediators of virus induced epithelial damage in influenza infected mice [8]. The source of these oxidants may be leukocytes, xanthine oxidase, which is increased in influenza- 
infected lungs [8], or lung epithelial cells themselves $[9,10]$. Oxidative stress is one of the components of the pathophysiology of COPD [11]. There are more reactive oxygen species in COPD patients than in healthy people, probably due to alterations in some enzymes including glutathione-S-transferase [12], catalase [13], and superoxide dismutase [14]. ROIs are necessary for virus infection and are involved in the inflammatory response of host cells, induced by respiratory viruses. For example, RSV increases catalase, glutathione S-transferase and glutathione peroxidase activity [15] leading to an increase in ROS generation that is responsible for the induction of different inflammatory mediators like TNF-alpha or IL8 [16]. An oxidative environment is necessary for influenza replication to [17]. Elevation of mitochondrial superoxide increases susceptibility to influenza infection in mice [18] and in A549 [19]. ROS induction after influenza infection increases the expression of pro-inflammatory molecules like IL8, IL6, CCL5 or CXCL10 [20]. These effects have been associated with the activation of NF-kB [16] and p38 MAPK [20].

Sputum volume and virulence are one of the main symptoms related to exacerbations [2]. MUC5AC is the predominant mucin gene expressed in healthy human airways and its expression is augmented in asthmatic and COPD patients [21,22]. Rhinovirus, one of the main viruses involved in asthma and COPD exacerbations, induces MUC5AC expression in A549 cells [23] as RSV and influenza viruses do [24, 25]. NF-kB and p38 MAPK phosphorylation have been associated with the increase of MUC5AC expression in both human bronchial tissue and A549 [26].

$\mathrm{N}$-acetyl-cysteine (NAC) is a thiol compound that acts directly as a free radical scavenger and as a precursor of reduced glutathione (GSH) [27]. This molecule reduces the number 
and impact of COPD exacerbations [28] and also the inflammatory response in epithelial cells exposed to H5N1 influenza A virus [20]. Although anti-mucolitic effects of NAC are well established, little is known about its effects on the MUC5AC expression in virus models of infection.

In this study, we investigate the effects of NAC on virus replication, MUC5AC production and pro-inflammatory cytokine expression in an in vitro model developed in A549 alveolar type II cells infected with influenza (strains A and B) and Respiratory Syncytial Virus. We analyze the infection effects on the intracellular thiols levels and $\mathrm{H}_{2} \mathrm{O}_{2}$ generation and the modulatory effect of NAC on these parameters. Finally we will explore the role of $\mathrm{NF}-\kappa \mathrm{B}$ as key regulator of inflammatory cellular response to virus injury.

\section{MATERIALS AND METHODS}

\subsection{Cell model and experimental groups}

Human pulmonary epithelial cell line A549 derived from lung alveolar carcinoma and representative of human epithelial cell line [29] was purchased from ATCC (American Type Culture Collection; Rockville, MD, USA). Cells were growth on $35 \mathrm{~mm}$ 6-well culture plates ( Sarstdet, Inc. Newton, NC USA) in RPMI containing 10\% endotoxin-free FBS, L-Glutamine $4 \mathrm{mM}$, penicillin $(100 \mathrm{u} / \mathrm{ml})$ and amphotericin $\mathrm{B}(0.25 \mu \mathrm{g} / \mathrm{ml})$ (Invitrogen Ltd., Paisley, UK). When the cultures were confluent, cells were washed and infected with influenza viruses in presence or absence of NAC (Sigma Aldrich St. Louise, MO, USA). The following experimental groups were considered: Control (untreated and uninfected cells), infected (cells infected with influenza A, influenza B or 
RSV viruses), infected and treated (cells infected with viruses in presence or absence of NAC 0.1-10 mM), and only treated (uninfected cells treated with NAC 0.1-10 mM).

NAC was added to the culture medium 1 hour before infection and maintained to the end of the experiment. Concentrations between 0.1 and $10 \mathrm{mM}$ were tested. To perform viral infection, A549 cells were grown in shell vials (Pacific Vial, Commerce, CA, USA) and inoculated with influenza A or B or RSV at a multiplicity of infection (MOI) of 0.3. After incubation in serum-free medium for 1 hour, supernatants were removed and replaced with fresh medium. At specific time points cells or supernatants were collected for MUC5AC, TNF-alpha, IL8, IL6, intracellular thiols, $\mathrm{H}_{2} \mathrm{O}_{2}, \mathrm{NF}-\mathrm{\kappa B}$ activation and p38 MAPK phosphorylation determinations.

\subsection{Preparation of virus}

Influenza virus strain A/ Port Chlamers/1/72 (H3N2) (ATCC VR 810) and strain B/Hong Kong/5/72 were grown in Madin-Darby canine kidney cells in DMEM and semi purified by two cycles of differential centrifugation from the infected culture supernatants. RSV (long Strain, ATCC VR-26) was propagated in Hep-2 cells and purified by centrifugation at $65000 \mathrm{x} \mathrm{g}$ for $2 \mathrm{~h}$ at $4^{\circ} \mathrm{C}$ in $50 \%$ sucrose-PBS. Virus stocks were stored at $-80^{\circ} \mathrm{C}$. The viral content of this virus stock was determined by immunofluorescence assay (Millipore, Billerica, MA, USA), by counting fluorescent cells after inoculation of a shell vial (by six duplicates) and 4 days of incubation. All viruses and cells were obtained from the (American Type Culture Collection; Rockville, MD, USA).

Viruses' titres were determined as 50\% tissue culture infection dose (TCID50/ml) in confluent cells in 96-well culture plates (Sarstdet, Inc. Newton, NC USA). 


\subsection{Determination of MUC5AC, TNF-alpha, IL8 and IL6 mRNA}

Mucin MUC5AC mRNA transcripts were measured by real-time RT-PCR as previously reported [24]. Total RNA was isolated with TriZol Reagent (Invitrogen Ltd., Paisley, UK) following manufacturer's instructions. Integrity was measured by a 2100 bioanalyzer (Agilent Technologies Inc., Santa Clara, CA, US). Only extractions with an integrity ratio (28S/18S) near 2.0 were considered. Two hundred nanograms of total RNA were cDNA transcribed using TaqMan RT reagents (Applied Biosystems, Foster City, CA, US), as indicated by the manufacturer. GAPDH was used as an internal control. Primers and probes for both MUC5AC and GAPDH were designed using Primer Express software, as previously reported [26]. For TNF-alpha IL8, and IL6 determination, assays on demand Applied Biosystems, Foster City, CA, US) were performed. The $\Delta \Delta \mathrm{Ct}$ method was used to obtain semi-comparative data.

\subsection{Determination of TNF-alpha, IL8 and IL6 protein in supernatants.}

48 hours after infection, $50 \mu \mathrm{L}$ of culture supernatants were collected and analyzed for TNF-alpha, IL8 and IL6 release using a multiplex cytometer based method (Luminex DX100, Luminex Corp., Austin TX, US). Panels and specific bead conjugated antibodies were purchased from $R \& D$ (R\&D Systems Inc., Mineapolis, MN, US), and determinations were carried out following manufacturer instructions. 


\subsection{Determination of MUC5AC protein}

MUC5AC protein measurement by ELISA was carried out as previously outlined [30]. $100 \mu \mathrm{L}$ of culture supernatants were mixed $1: 1$ with bicarbonate-carbonate buffer at $40^{\circ} \mathrm{C}$ in a 96-well plate ( Sarstdet, Inc. Newton, NC USA) and incubated until dry. Plates were washed with PBS (Sigma, St Louis, MO, USA) and blocked with 2\% BSA (fraction V; Sigma, St Louis, MO, USA) for $1 \mathrm{~h}$ at room temperature. After three washes, plates were incubated with $50 \mu \mathrm{L}$ of mouse mAb (Lab Vision, Thermo Fischer Scientific, Fremont, CA, US) at 1:100. $1 \mathrm{~h}$ later, plates were washed with PBS and then incubated with 100 $\mu \mathrm{L}$ of horseradish peroxidase-goat antimouse immunoglobulin $\mathrm{G}$ conjugated at 1:10000 (Sigma, St Louis, MO, USA). Colour reaction was developed with TMB peroxidase solution (Sigma, St Louis, MO, USA) and stopped with $1 \mathrm{M} \mathrm{H}_{2} \mathrm{SO}_{4}$ (Panreac Quimica, Barcelona, Spain). Absorbance was read at $450 \mathrm{~nm}$. The corresponding negative controls were carried out without tissue protein or in the absence of primary antibody (data not shown).

\subsection{Determination of intracellular $\mathrm{H}_{2} \mathrm{O}_{2}$ concentration}

Intracellular levels of $\mathrm{H}_{2} \mathrm{O}_{2}$ were determined using the Amplex Red Reagent (Invitrogen Ltd., Paisley, UK) as previously described [32]. Cells were grown in 12 well culture plates (Sarstdet, Inc. Newton, NC USA) and lysed in $100 \mu \mathrm{M}$ Amplex red solution supplemented with $2 \mathrm{U} / \mathrm{ml} \mathrm{HRP}$ and $200 \mathrm{mU} / \mathrm{ml}$ superoxide dismutase (OXIS International Inc., Beverly Hills, CA, US) and incubated in the dark for $30 \mathrm{~min}$. Fluorescence was measured in a plate reader at excitation/emission wavelengths $\lambda_{\mathrm{EX}}=$ $540 \mathrm{~nm} / \lambda_{\mathrm{EM}}=590 \mathrm{~nm}$, respectively. 


\subsection{Determination of thiols by flow cytometry}

The total intracellular thiol concentration was measured with 5-chloromethylfluorescein diacetate (CMFDA) staining by flow cytometry, according to Täger et al. [31]. CMFDA was obtained from Molecular Probes (Invitrogen Ltd., Paisley, UK) and dissolved in dimethyl sulfoxide (Panreac Quimica, Barcelona, Spain). Working solutions in PBS at 20 times the required final concentration were prepared immediately before use. Cell samples were stained with CFMDA at a final concentration of $12.5 \mu \mathrm{M}$ in phosphate buffer saline for $15 \mathrm{~min}$ at room temperature. After washing the cells were fixed in $1 \%$ paraformaldehyde (Panreac Quimica, Barcelona, Spain) and analyzed within $2 \mathrm{~h}$ by flow cytometry (Beckman Coulter Epics XL, Beckman Coulter Inc., Brea, CA, US) at excitation/emission wavelengths $\lambda_{\mathrm{EX}}=490 \mathrm{~nm} / \lambda_{\mathrm{EM}}=520 \mathrm{~nm}$, respectively. Fluorescence was recorded before (blank) and after adding the probe and results were presented as fluorescence arbitrary units after subtracting the blank values. Cells were defined by forward/side scatting and gated for analysis. The levels of intracellular thiols were indicated by mean fluorescence intensities of stained probes versus negative controls. In additional experiments, cellular stores of reduced glutathione were depleted with $\mathrm{N}$-ethyl maleimide (NEM, Sigma, St Louis, MO, USA) $100 \mu \mathrm{M}$ for 1 hour to reduce the intracellular glutathione (data not shown).

\subsection{Determination of $N F-\kappa B$ activation.}

The Nuclear factor kappa B (NF-kB ) activation was measured according to Blesa et al. [33]. Aliquots of nuclear extracts with equal amounts of protein $(10 \mu \mathrm{g})$ were processed 
according to the manufacturers' instructions (DIG gel shift kit; Boehringer Mannheim, Mannheim, Germany, and Enzo Diagnostics, Inc., Farmingdale, NY, USA). Binding reactions started by addition of 30 fmol of double-stranded digoxigenin-labelled NFkB oligonucleotide (sense-strand sequence 5'-AGTTGAGGGGACTTTCCCAGGC-3', GGGGACTTTCC being a $\kappa$ B binding motif) from Promega Co. (Madison, WI, USA). Samples were analysed on a $6 \%$ non-denaturating polyacrylamide gel. After electrophoretic transfer to a nylon membrane (Hybond-N+; Amersham Pharmacia Biotech Europe GmbH, Freiburg, Germany), complexes were visualised using a chemiluminescence detection system. In order to ascertain the specificity of the binding reaction, competition assays were performed in the presence of an 100-fold excess (i.e. 3,000 fmol) of unlabelled oligonucleotide.

\subsection{Western blot analysis}

Phosphorylation of p38 MAPK was evaluated by western blot using specific antibodies against phospho p38 MAPK (Thr180/Tyr182) mAb (28B10; Cell Signaling Technology, Beverly, MA, USA), as previously described [26]. Aliquots of supernatant containing cytosolic proteins were loaded onto a $10 \%$ polyacrylamide gel and submitted to sodium dodecyl sulphate polyacrylamide gel electrophoresis. Proteins were transferred to nitrocellulose membranes (Protran ${ }^{\circledR}$, Schleicher \& Schuell, Keene, NH, USA), which were incubated in a blocking solution containing the primary antibody (1:500) or $\beta$-actin mouse monoclonal antibody (Sigma-Aldrich Corporation, St Louis, MO, USA; 1:10,000 dilution). The secondary antibodies (1:5,000 dilution), horseradish peroxidase-linked donkey mouse immunoglobulin $\mathrm{G}$ directed against phospho p38 and horseradish 
peroxidase-linked sheep antimouse immunoglobulin $G$ directed against $\beta$-actin (Amersham Pharmacia Biotech Europe $\mathrm{GmbH}$ ), were incubated in blocking solution for 2 $\mathrm{h}$ at $22^{\circ} \mathrm{C}$. Immunoreactivity was detected with an enhanced chemiluminescence Western blot detection system (Amersham Pharmacia Biotech Europe GmbH).

\subsection{Analysis of results}

Data are presented as mean \pm SEM. Statistical analysis of results was carried out by analysis of variance (ANOVA) followed by Tukey's Multiple Comparison Test, or t-test, as appropriate (GraphPad Software Inc, San Diego, CA, USA). Significance was accepted when $P<0.05$.

\section{RESULTS}

\subsection{Effects of viral infection on oxidative cell status}

Oxidative stress mediated events are involved in virus infection mechanisms and correlated with mucin and inflammatory mediators release from human epithelial cells. To explore the implication of ROS production we analyzed both, the intracellular changes in hydroxide peroxide concentration and the thiols levels.

For the intracellular $\mathrm{H}_{2} \mathrm{O}_{2}$ studies, cells were grown and after confluence, infected with $\mathrm{RSV}$, influenza A or influenza B in the presence or absence of NAC $10 \mathrm{mM}$. 48 hours later the cells were lysed and $\mathrm{H}_{2} \mathrm{O}_{2}$ concentration was estimated using the Amplex red reactive as described above. As an effect of infection, the intracellular level of hydroxide peroxide significantly increased, compared to mock treated cultures. Induction was 
higher in influenza A infected cells (2.76-fold increase) than in RSV (2.28-fold increase) or in influenza B (1.90-fold increase). In the three experimental groups, pre-treatment with NAC $10 \mathrm{mM}$ totally abolished the increase in $\mathrm{H}_{2} \mathrm{O}_{2}$ production (Fig. 1).

For the intracellular thiols level estimation after infection, cells were trypsinized, stained with CMFDA and analyzed by flow cytometry. Our results indicate a reduction in the total thiol content after virus infection that was reverted by effect of pre-treatment with NAC $10 \mathrm{mM}$ (Fig. 2).

\subsection{Effects of viral infection on MUC5AC expression}

COPD exacerbations are characterized by different symptoms including mucus hypersecretion. To investigate the effects of viral infections in our model, A549 cells were infected with influenza virus A, B or RSV as described above in the presence or absence of NAC. We used three different doses of NAC $(0.1 \mathrm{mM}, 1 \mathrm{mM}$ and $10 \mathrm{mM})$ to analyze if the effects observed were dose dependent. 48 hours after infection supernatants were collected for MUC5AC protein analysis and total RNA was extracted to study the MUC5AC expression.

NAC significantly reduces the MUC5AC expression in A549 infected cells in a dose dependent manner showing a IC50 of 1.3, 0.45 and 0.39 for RSV, influenza A and influenza B, respectively (Fig. 3, panels A, B and C, white bars). Similar results were observed for MUC5AC release with IC50 values of $0.33,0.26$ and 0.79 for RSV, influenza A and influenza B, respectively (Fig. 3, panels A, B and C, squared bars).

\subsection{Effects of viral infection on interleukin release}


During exacerbations there is a release of different chemokines and cytokines from different sources including airway epithelial cells. The inhibitory effects of NAC on the release and expression of TNF-alpha, IL6 and IL8 were studied. 48 hours after A549 cell infection with the viruses, culture supernatants were collected and analyzed by flow cytometry as described in the methods section. Total RNA was extracted from the cells, and the gene expression was evaluated by real time RT-PCR. The obtained results are summarized in figure 4 .

Analysis of supernatants revealed that baseline levels of TNF-alpha and IL8 were very low (36.62 and $124.09 \mathrm{pg} / \mathrm{ml}$ for TNF-alpha and IL8 respectively). The amount of IL6 was undetectable in mock treated cells. After infection there was a high induction in the release of the three cytokines analyzed.

NAC $10 \mathrm{mM}$ pre-treatment almost abolished induction of TNF-alpha after virus infection with RSV and influenza A. In influenza B infected cells the inhibition was lower but significant compared to mock-treated cells. IL8 protein inhibition didn't reach statistical significance compared to infected cells, but levels were closer to mock-treated groups (in fact there aren't statistical differences between them). In the case of IL6, NAC pretreatment totally abolished protein release in RSV infected cells and almost totally in influenza A and B cultures.

For gene expression a similar profile to the one for protein release was observed. One remarkable thing is that baseline levels of messenger RNA for IL6 (not for protein) were found. In RSV infected cells, we found a higher inhibition in protein release of TNFalpha than in gene expression (although inhibition is significantly different than in infected cells). 


\subsection{NF- $\kappa B$ activation and $p 38$ phosphorylation}

NF- $\mathrm{kB}$ nuclear translocation and p38 MAPK phophorilation are commonly activated in response to ROS, and correlated with MUC5AC release. For this reason we decided to study the implication of these regulating proteins in our model. Cells were infected with the three different viruses included in this study in the presence or absence of NAC 10 mM. 48 hours after incubations, cells were scraped, lysed in buffer $\mathrm{C}$ and nucleus separated from the cytoplasmatic fraction by centrifugation. Nuclear protein extracts were used for NF- $\mathrm{kB}$ activation studies by EMSA, while phosphorylation of $\mathrm{p} 38$ was explored by western blot in the cytoplasmatic fractions. Representative results are displayed in figure 5. An activation of NF- $\mathrm{kB}$ and $\mathrm{p} 38$ MAPK phosphorylation as a consequence of viral infection can be seen. Both events are blocked by NAC $10 \mathrm{mM}$ in pre-treated cultures.

\subsection{Effects of NAC on virus replication}

To evaluate the effects of NAC on virus replication, A549 cells were grown and after confluence were infected with influenza virus A, B or RSV, as described above in the presence or absence of NAC $10 \mathrm{mM}$. 48 hours later, supernatants were collected and virus titres were determined as $\mathrm{TCID}_{50} / \mathrm{ml}$ (Fig. 6). NAC $10 \mathrm{mM}$, compared to mocktreated virus control, significantly reduced the virus titre in $10.31 \%, 12.99 \%$ and $30.12 \%$ (percentage of inhibition) for RSV, influenza A and influenza B infected cultures respectively. 


\section{DISCUSSION}

We have studied the effects of NAC on mucin synthesis, IL8, IL6 and TNF-alpha in a well established in vitro model of virus infection, using three different common respiratory viruses (2 strains of influenza A, and B, and one strain of RSV). Human alveolar type II cell line A549 has been used as host cell.

There are three different types of influenza virus: A, B and C. Type A can infect people, birds, pigs, horses, seals whales and other animals and can cause pandemics. Type B is normally found in humans and unlike type A, it can cause epidemics but not pandemics. Finally type $\mathrm{C}$ can cause mild illness in humans but does not cause epidemics or pandemics. Influenza B is generally considered to be less pathogenic with little impact on morbidity and mortality than influenza A [34]. However, it can cause severe pneumonia and septic shock in healthy people [35]. This is the reason why we have decided to include it in this study. No significant differences in A549 cell response to strain A or B have been found. This suggest that differences between morbidity of the two strains, at least at the epithelial level, are due to differences in infectivity capability of virus better than to the responsiveness of airway epithelia to infection. We have also included one strain of RSV because it represents the most frequent viral respiratory cause of hospitalization in infants and young children worldwide [36] and because it is strongly related to asthma [36] and COPD exacerbations [37]. We have found no differences either between RSV and influenza infection, which means that MUC5AC overexpression in A549 cells to the two types of viruses is similar.

Data presented here demonstrate that NAC inhibits, in a dose dependent manner, the induction of MUC5AC (RNA and protein) after virus infection. To our knowledge, this is 
the first report that demonstrates the inhibition of this mucin for both influenza and RSV in in-vitro models.

Respiratory viruses increase not only the frequency of exacerbations in COPD but also the severity of the airway inflammation, increasing the number of neutrophils in sputum and the levels of IL8 and IL6 [6]. In our model, NAC blocked the induction of both cytokines at the dose of $10 \mathrm{mM}$ at the expression and at the release level. These results are in line with those recently published by Geiler et al. [20] in an in vitro model of influenza A infection in A549. Similar effects of NAC for IL8 release in A549 after RSV infection have been reported [16]. To our knowledge, this is the first report of this effect of NAC for influenza virus strain B. Respiratory viruses, including influenza and RSV, induce apoptosis in epithelial cells through mechanisms involving TNF-alpha [38, 39]. We observed a strong induction of TNF-alpha expression and release after virus infection that was significant inhibited in NAC $10 \mathrm{mM}$ pre-treated cultures, in line with previously reported results $[16,20]$.

Oxidative stress contributes to the pathogenesis of COPD [11] and it is very important for respiratory virus infection to the host cells. There are studies that demonstrate that oxidative stress increases the susceptibility to viral infection for RSV and influenza viruses $[19,40]$. Our data indicate that after virus infection there is an increase of intracellular levels of $\mathrm{H}_{2} \mathrm{O}_{2}$ and a decrease of intracellular thiols. NAC restores this imbalance decreasing the $\mathrm{H}_{2} \mathrm{O}_{2}$ concentration and restoring the thiols levels in our model. As a consequence, there is a decrease of virus titres and an inhibition of proliferation for the three viruses assayed. This antioxidant effect on the virus replication has been described for other antioxidants like oligonol [41]. 
Most of the effects observed for respiratory virus pathogenity have been associated to an activation of NF-kB and MAPK through oxidant dependent mechanisms $[41,39,16,20]$. We have previously reported that activation of NF- $\mathrm{kB}$ and phophorilation of MAPK p38 are involved in MUC5AC induction in human bronchial cells [26]. Our results demonstrate an induction of NF- $\mathrm{kB}$ and an activation of $\mathrm{p} 38$ MAPK after virus infections that are completely abolished by NAC $10 \mathrm{mM}$. These findings explain the inihibition of the MUC5AC over-expression.

In summary, $64 \%$ of COPD exacerbations are associated with respiratory viruses infection including RSV and influenza A and B. NAC is a gluthathione precursor that reduces symptoms and exacerbations in COPD patients [42] and its beneficial effects in the treatment of COPD are well established [43]. The results of this study indicate that NAC inhibits the MUC5AC, IL8, IL6 and TNF-alpha expression that follows virus infection through mechanisms involving ROS generation and subsequent NF- $\mathrm{KB}$ and $\mathrm{p} 38$ MAPK activation. These results support the beneficial effects of NAC treatment observed in the management of COPD [43].

\section{ACKNOWLEDGEMENTS}

This work was supported by grants SAF2005-00669/SAF2008-03113 (JC), PI10/02294

(MM), and CIBERES (CB06/06/0027) from Ministry of Science and Innovation and Health Institute 'Carlos III' of Spanish Government and research grants from Regional Government (GV2007/287 and AP073/10, from Generalitat Valenciana).

\section{REFERENCES}


[1] Demedts IK, Demoor T, Bracke KR, Joos GF and Brusselle GG. Role of apoptosis in the pathogenesis of COPD and pulmonary emphysema. Respir Res $2006 ; 7: 53$.

[2] Malia P. and Johnson SL. How viral infections causes exacerbations of airway diseases. CHEST 2006; 130(4): 1203-10.

[3] Beasley R, Coleman ED, Iiermon Y et al. Relationship between exacerbation frequency and lung function decline in chronic obstructive pulmonary disease. Thorax 2002 57:847-52.

[4] Donaldson GC, Seemungal TA, Patel IS, et al. Longitudinal changes in the nature, severity and frequency of COPD exacerbations. Eur Respir J, 2003 (22): 931-36.

[5] Donaldson GC, Seemungal TAR, Bhowmik A, Wedzycha JA. The relationship between exacerbation frequency and lung function decline in chronic obstructive pulmonary disease. Thorax 2002; 57: 847-852.

[6] Wedzycha JA. Role of viruses in exacerbations of chronic obstructive pulmonary disease. Proc Am Thorac Soc 2004; 1: 115-20.

[7] Nichol KL, Baken I, Nelson A. Relation between vaccination and out patient visits, hospitalization and mortality in elderly persons with chronic lung disease. Ann Intern Med 1999; 130: 397-403.

[8] Akaike TM, Ando T, Oda T, Doi S, Ijiri S, Araki S, and Maeda H. Dependence on $\mathrm{O} 2$ - generation by xanthine oxidase of pathogenesis of influenza virus infection in mice. J Clin Invest 1990; 85: 739-45. 
[9] Jacoby DB and Choi AM. Influenza virus infection induces differential expression of antioxidant genes in human airway epithelial cells. Free Radic Biol Med 1994; 6: 821-24.

[10] Kinnula VL, Adler KB, Ackley NJ and Crapo JD. Release of reactive oxygen species by guinea pig tracheal epithelial cells in vitro. Am J Physiol 1992; 262: L708-12.

[11] MacNee W: Oxidants/antioxidants and COPD. Chest 2000; 117(5 Suppl 1):303S-17S.

[12] Mannervik B: The isoenzymes of glutathione transferase. Adv Enzymol Relat Areas Mol Biol 1985; 57:357-417.

[13] Wood AM and Stockley RA. The genetics of chronic obstructive pulmonary disease. Respir Res 2006; 7: 130.

[14] Young RP, Hopkins R, Black PN, Eddy C, Wu L, Gamble GD, Mills GD, Garrett JE, Eaton TE, Rees MI. Functional variants of antioxidant genes in smokers with COPD and in those with normal lung function. Thorax 2006; 61(5):394-399.

[15] Hosakote YM, Liu T, Castro SM, Garofalo RP, Casola A. Respiratory syncytial virus induces oxidative stress by modulating antioxidant enzymes. Am J Respir Cell Mol Biol 2009; 41(3):348-57.

Carpenter LR, Moy JN, Roebuck KA. Respiratory syncytial virus and TNF alpha induction of chemokine gene expression involves differential activation of Rel A and NF-kappa B1. BMC Infect Dis 2002; 2:5. 

recombinant human catalase on $\mathrm{H} 1 \mathrm{~N} 1$ influenza-induced pneumonia in mice. Inflammation 2010; 33(3):166-72.

[18] Case AJ, McGill JL, Tygrett LT, Shirasawa T, Spitz DR, Waldschmidt TJ, Legge KL, Domann FE. Elevated mitochondrial superoxide disrupts normal T cell development, impairing adaptive immune responses to an influenza challenge. Free Radic Biol Med 2011; 50(3):448-58.

[19] Jaspers I, Ciencewicki JM, Zhang W, Brighton LE, Carson JL, Beck MA, Madden MC. Diesel exhaust enhances influenza virus infections in respiratory epithelial cells. Toxicol Sci 2005; 85(2):990-1002.

[20] Geiler J, Michaelis M, Naczk P, Leutz A, Langer K, Doerr HW, Cinatl J Jr. N-acetyl-L-cysteine (NAC) inhibits virus replication and expression of proinflammatory molecules in A549 cells infected with highly pathogenic H5N1 influenza A virus. Biochem Pharmacol. 2010 Feb 1;79(3):413-20.

[21] Takeyama K, Fahy JV, Nadel JA. Relationship of epidermal growth factor receptors to goblet cell production in human bronchi. Am J Respir Crit Care Med 2001; 163(2):511-6.

[22] Leikauf GD, Borchers MT, Prows DR, Simpson LG. Mucin apoprotein expression in COPD. Chest. 2002; 121(5 Suppl):166S-182S.

[23] Zhu L, Lee PK, Lee WM, Zhao Y, Yu D, Chen Y. Rhinovirus-induced major airway mucin production involves a novel TLR3-EGFR-dependent pathway. Am J Respir Cell Mol Biol 2009; 40(5):610-9. 
GC, Adderson EE. Respiratory viruses augment the adhesion of bacterial pathogens to respiratory epithelium in a viral species- and cell type-dependent manner. J Virol. 2006 Feb;80(4):1629-36.

W, Suzutani T, Jones PW, Goleniewska K, O'Neal JF, Peebles RS Jr. Respiratory syncytial virus in allergic lung inflammation increases MUC5AC and gob-5. Am J Respir Crit Care Med. 2004 Aug 1;170(3):306-12.

Mata M, Sarriá B, Buenestado A, Cortijo J, Cerda M, Morcillo EJ. Phosphodiesterase 4 inhibition decreases MUC5AC expression induced by epidermal growth factor in human epithelial cells. Thorax 2005 60(2): 144-52.

Cotgreave IA. N-Acetylcysteine: pharmacological considerations and experimental and clinical applications. Adv Pharmacol 1997; 38: 205-227.

[28] Dekhuijzen PN, van Beurden WJ. The role for N-acetylcysteine in the management of COPD. Int J Chron Obstruct Pulmon Dis. 2006;1(2):99-106.

[29] Mitchell JA, Belvisi MG, Akarasereenont P, Robbins RA, Kwon OJ, Croxtall J, Barnes PJ, Vane JR. Induction of cyclo-oxygenase-2 by cytokines in human pulmonary epithelial cells: regulation by dexamethasone. Br J Pharmacol 1994 113(3):1008-14.

Mata M, Ruíz A, Cerdá M, Martinez-Losa M, Cortijo J, Santangelo F, Serrano-Mollar A, Llombart-Bosch A, Morcillo EJ. Oral N-acetylcysteine reduces bleomycin-induced lung damage and mucin MUC5AC expression in rats. Eur Respir J 2003; 22(6): 900-5. 

a defective thiol status of alveolar macrophages from COPD patients and smokers. Free Rad Biol Med 2000; 29:1160-1165.

$$
\text { Bell EL, Klimova TA, Eisenbart J, Moraes CT, Murphy MP, Budinger }
$$

GR, Chandel NS. The Qo site of the mitochondrial complex III is required for the transduction of hypoxic signaling via reactive oxygen species production. J Cell Biol 2007; 177(6):1029-36. Suchankova J, Morcillo EJ. Oral N-acetylcysteine attenuates the rat pulmonary inflammatory response to antigen. Eur Respir J. 2003 21(3):394-400.

$$
\text { Wressnigg N, Voss D, Wolff T, Romanova J, Ruthsatz T, Mayerhofer I, }
$$
Reiter M, Nakowitsch S, Humer J, Morokutti A, Muster T, Egorov A, Kittel C. Development of a live-attenuated influenza B DeltaNS1 intranasal vaccine candidate. Vaccine 2009; 27(21):2851-7. infection of Influenza B and Streptococci causing severe pneumonia and septic shock in healthy women. BMC Infect Dis 2010;10:308.

[36] Zeng R, Li C, Li N, Wei L, Cui Y. The role of cytokines and chemokines in severe respiratory syncytial virus infection and subsequent asthma. Cytokine. 2011 Jan;53(1):1-7.

[37] Ramaswamy M, Groskreutz DJ, Look DC. Recognizing the importance of respiratory syncytial virus in chronic obstructive pulmonary disease. COPD. 2009; 6(1):64-75. 
Cardona CJ. Host immune and apoptotic responses to avian influenza virus H9N2 in human tracheobronchial epithelial cells. Am J Respir Cell Mol Biol. 2011 Jan;44(1):24-33.

[39] Bitko V, Shulyayeva O, Mazumder B, Musiyenko A, Ramaswamy M, Look DC, Barik S. Nonstructural proteins of respiratory syncytial virus suppress premature apoptosis by an NF-kappaB-dependent, interferon-independent mechanism and facilitate virus growth. J Virol. 2007; 81(4):1786-95.

[40] Case AJ, McGill JL, Tygrett LT, Shirasawa T, Spitz DR, Waldschmidt TJ, Legge KL, Domann FE. Elevated mitochondrial superoxide disrupts normal T cell development, impairing adaptive immune responses to an influenza challenge. Free Radic Biol Med. 2011; 50(3):448-58.

Gangehei L, Ali M, Zhang W, Chen Z, Wakame K, Haidari M. Oligonol a low molecular weight polyphenol of lychee fruit extract inhibits proliferation of influenza virus by blocking reactive oxygen species-dependent ERK phosphorylation. Phytomedicine. 2010; 17(13):1047-56.

[42] Stey C, Steurer J, Bachmann S, Medici TC, Tramèr MR. The effect of oral $\mathrm{N}$-acetylcysteine in chronic bronchitis: a quantitative systematic review. Eur Respir J. 2000; 16(2):253-62.

Dekhuijzen PN, van Beurden WJ. The role for N-acetylcysteine in the management of COPD. Int J Chron Obstruct Pulmon Dis 2006; 1(2):99-106.

\section{FIGURE LEGENDS}


Fig.1. Effect of N-acetyl-L-cysteine (NAC) on intracellular $\mathrm{H}_{2} \mathrm{O}_{2}$ generation. A549 cells were infected with Respiratory Syncytial Virus (RSV), influenza virus strain A/ Port Chlamers/1/72 (H3N2) (ATCC VR 810) (IA) or strain B/Hong Kong/5/72 (IB) at a MOI of 0.3 in the absence or presence of NAC $10 \mathrm{mM} .48$ hours after infection cells were lysed and $\mathrm{H}_{2} \mathrm{O}_{2}$ concentration was determined using AmplexRed reagent. Data represents mean \pm SEM of three independent experiments. $* p<0.05$ compared to mock-treated cells. \# $\mathrm{p}<0.05$ compared to infected cells.

Fig.2. Effect of N-acetyl-L-cysteine (NAC) on intracellular thiol levels. A549 cells were infected with Respiratory Syncytial Virus (RSV), influenza virus strain A/ Port Chlamers/1/72 (H3N2) (ATCC VR 810) (IA) or strain B/Hong Kong/5/72 (IB) at a MOI of 0.3 in the presence (left) or absence (right) of NAC $10 \mathrm{mM} .48$ hours after infection cells were trypsinised and stained with 5-chloromethylfluorescein diacetate (CMFDA). Intracellular thiol content was determined by flow cytometry. FL1 indicates $\log$ fluorescence intensity of CMFDA stained cells. A representative experiment out of three is shown in each panel.

Fig.3. Influence of N-acetyl-L-cysteine (NAC) on mucin MUC5AC production. A549 cells were infected with Respiratory Syncytial Virus (RSV, panel A) influenza virus strain A/ Port Chlamers/1/72 (H3N2) (ATCC VR 810) (IA, panel B) or strain B/Hong Kong/5/72 (IB, panel C) at a MOI of 0.3 in the absence or presence of NAC $0.1,1$ or $10 \mathrm{mM} .48$ hours after infection supernatants were collected and analyzed for 
MUC5AC release using ELISA (squared bars) and for MUC5AC gene expression using Real-Time RT-PCR (white bars). Data represents mean \pm SEM of three independent experiments. ${ }^{*} \mathrm{p}<0.05$ compared to mock-treated cells. \# $\mathrm{p}<0.05$ compared to infected cells.

Fig.4. Influence of N-acetyl-L-cysteine (NAC) on TNF-alpha, IL8 and IL6 production in viruses-infected A549 cells. A549 cells were infected with Respiratory Syncytial Virus (RSV, panel A, D and G) influenza virus strain A/ Port Chlamers/1/72 (H3N2) (ATCC VR 810) (IA, panel B, E and H) or strain B/Hong Kong/5/72 (IB, panel C, F and I) at a MOI of 0.3 in the absence or prersence of NAC 10 mM. 48 hours after infection supernatants were collected and analyzed for TNFalpha (panels A, B and C), IL8 (panels D, E, and F) and IL6 (panels G, H and I) release using Luminex (squared bars) and for gene expression using Real-Time RTPCR (white bars). Data represents mean \pm SEM of three independent experiments. * $\mathrm{p}<0.05$ compared to mock-treated cells. \# $\mathrm{p}<0.05$ compared to infected cells.

Fig.5. Effect of N-acetyl-L-cysteine (NAC) on NF- $\mathrm{B}$ and p38 MAPK phosphorylation. A549 cells were infected with Respiratory Syncytial Virus (RSV, lanes B and C), influenza virus strain A/ Port Chlamers/1/72 (H3N2) (ATCC VR 810) (IA, lanes D and E) or strain B/Hong Kong/5/72 (IB, lanes F and G) at a MOI of 0.3 in the absence (lanes B, D and F) or presence of NAC $10 \mathrm{mM}$ (panels C, E, and H).48 hours after infection nuclear and cytosolic proteins were extracted and analyzed for NF- $\kappa \mathrm{B}$ activation (using EMSA) and p38 MAPK phosphorilation (using western- 
blot). Beta-acting was used as loading control. Results are representative of three independent experiments.

Fig.6. Influence of N-acetyl-L-cysteine (NAC) on RSV influenza A and influenza B replication in A549 cells. A549 cells were infected with influenza virus strain A/ Port Chlamers/1/72 (H3N2) (ATCC VR 810) (IA), strain B/Hong Kong/5/72 (IB) or respiratory Syncytial Virus (RSV) at a MOI of 0.3 in the absence (white bars) or absence (squared bars) of NAC $10 \mathrm{mM}$. Viruses titres were determined 48 hours postinfection. Data represents mean \pm SEM of three independent experiments. ${ }^{*} \mathrm{p}<0.05$ compared to infected cells cells. 


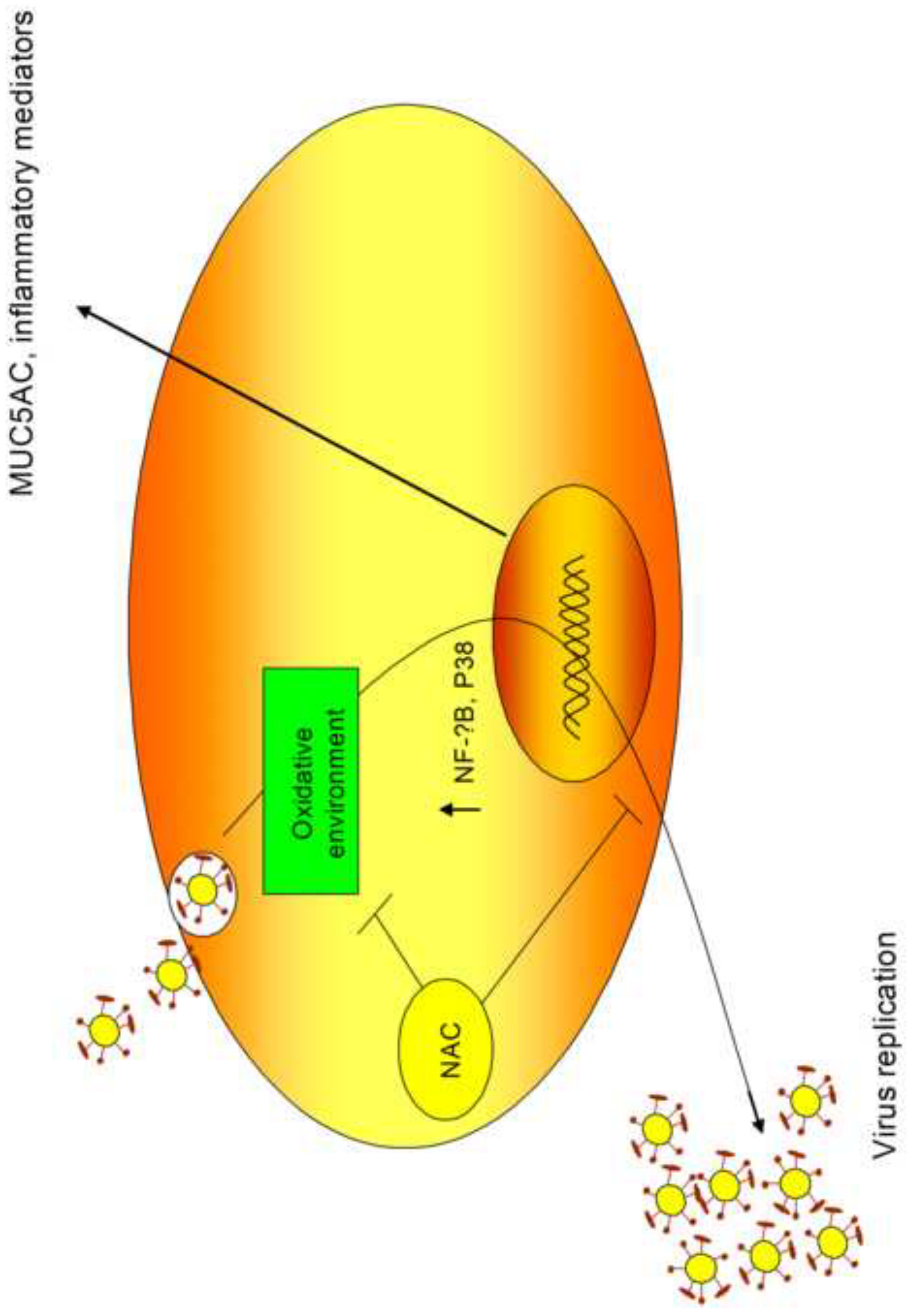

rage 27 of 33 


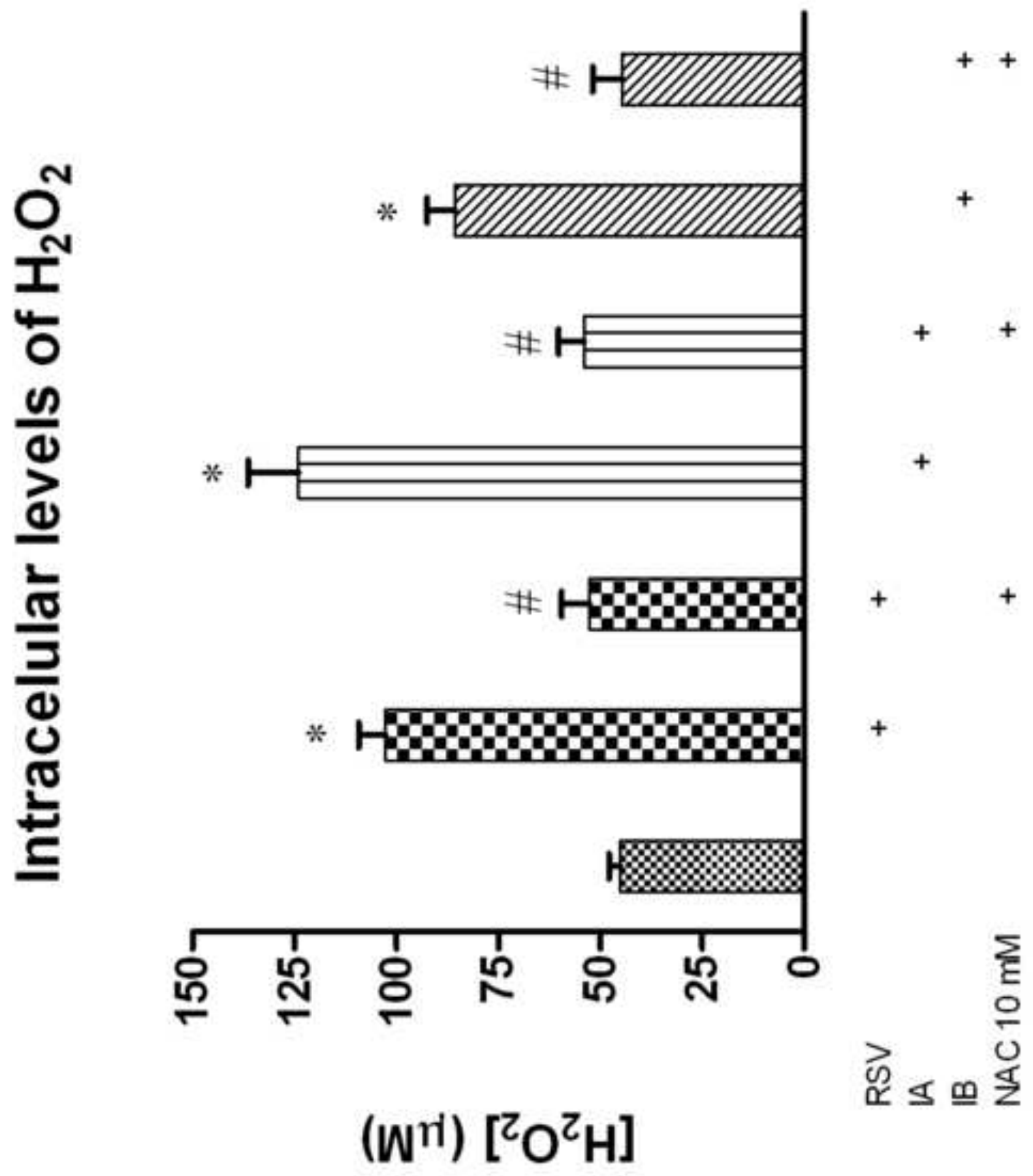

Page 28 of 33 


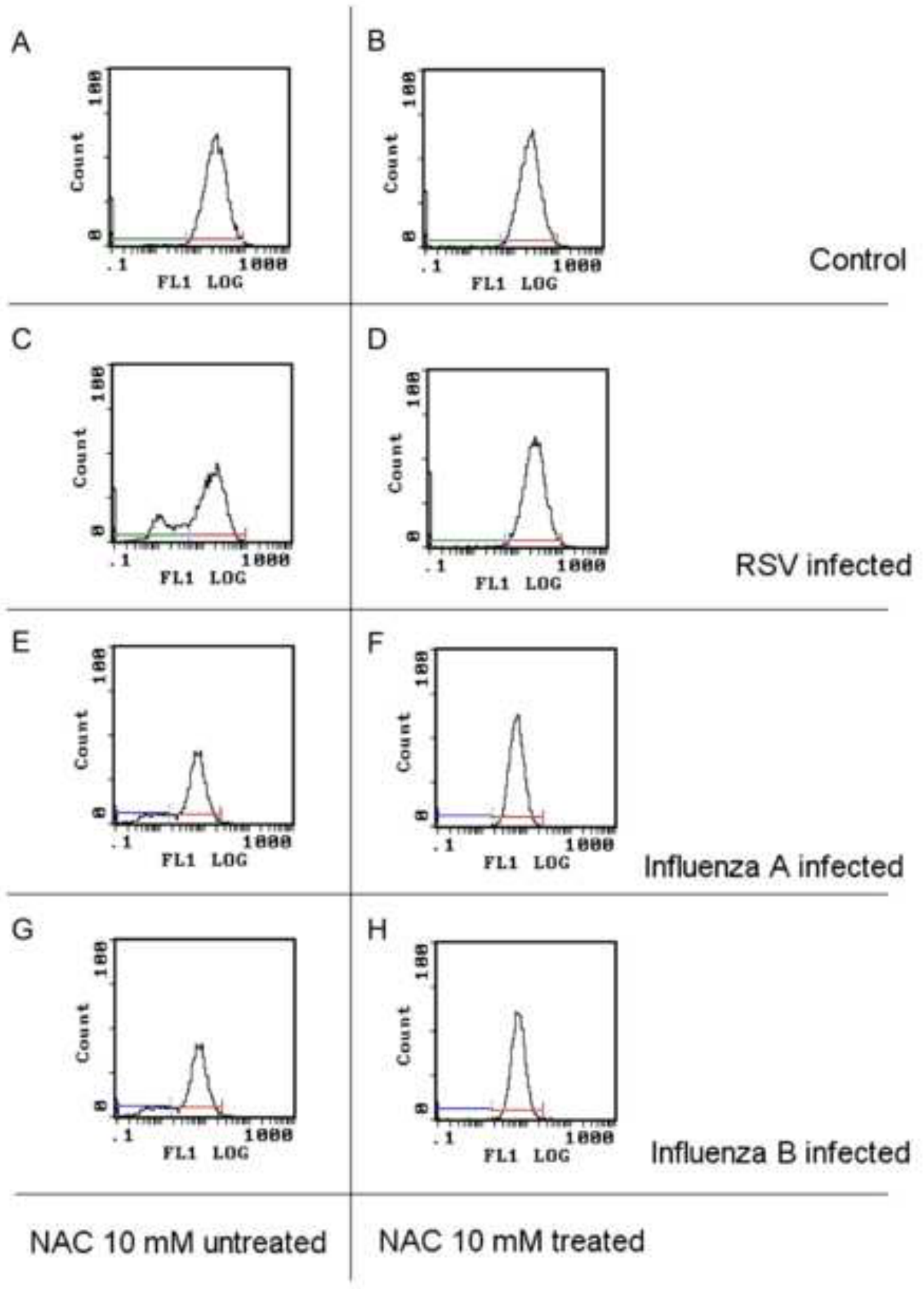


A MUC5AC expression A549 cells infected with RSV

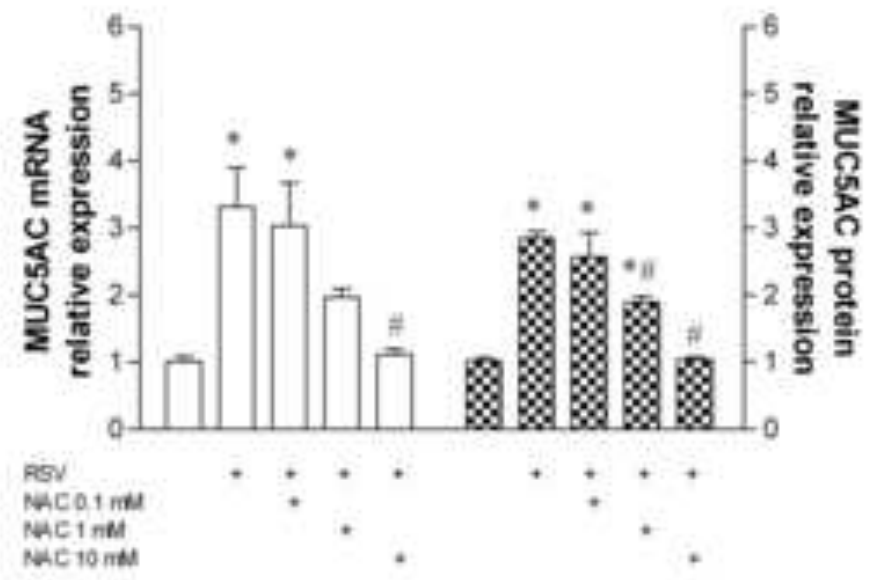

B MUC5AC expression A549 cells infected with influenza A

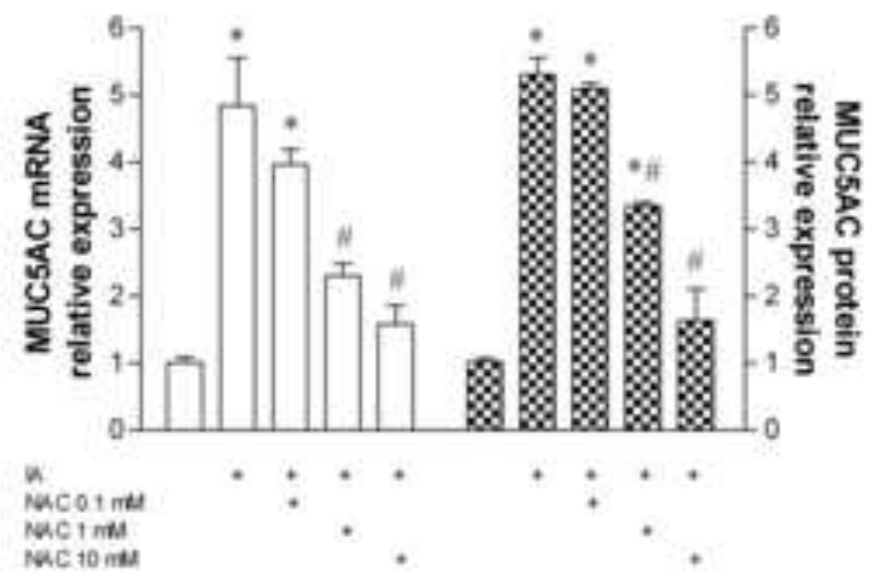

C MUC5AC expression A549 cells infected with influenza B

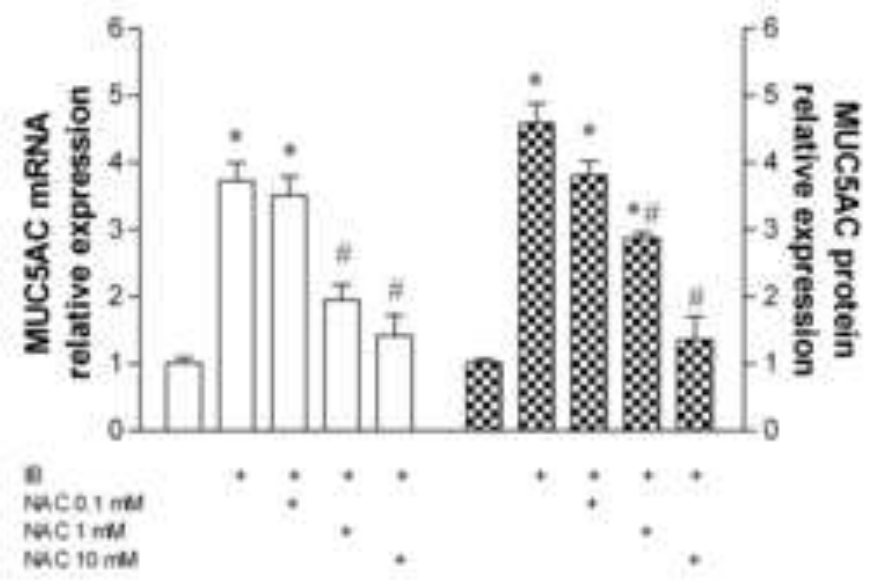



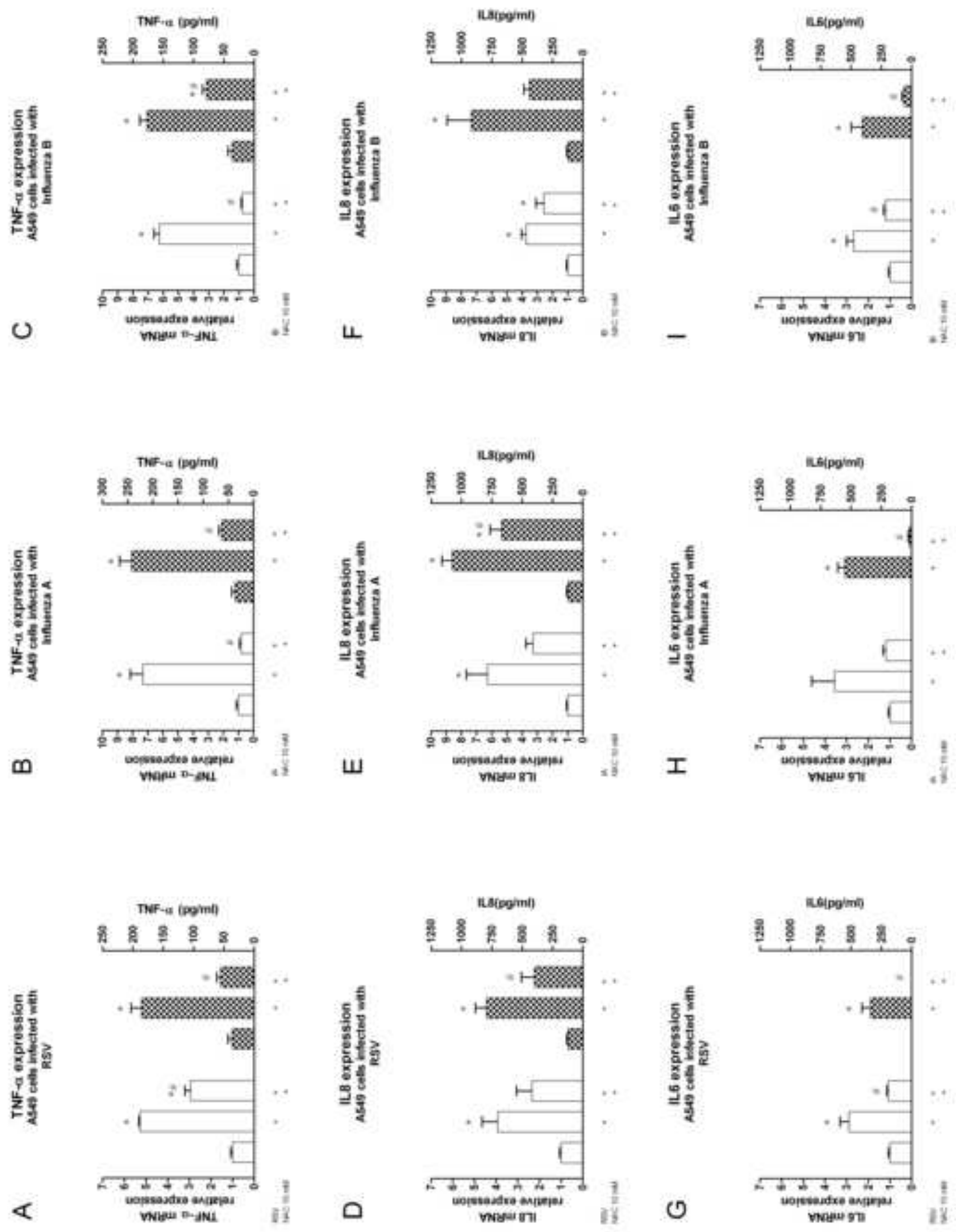


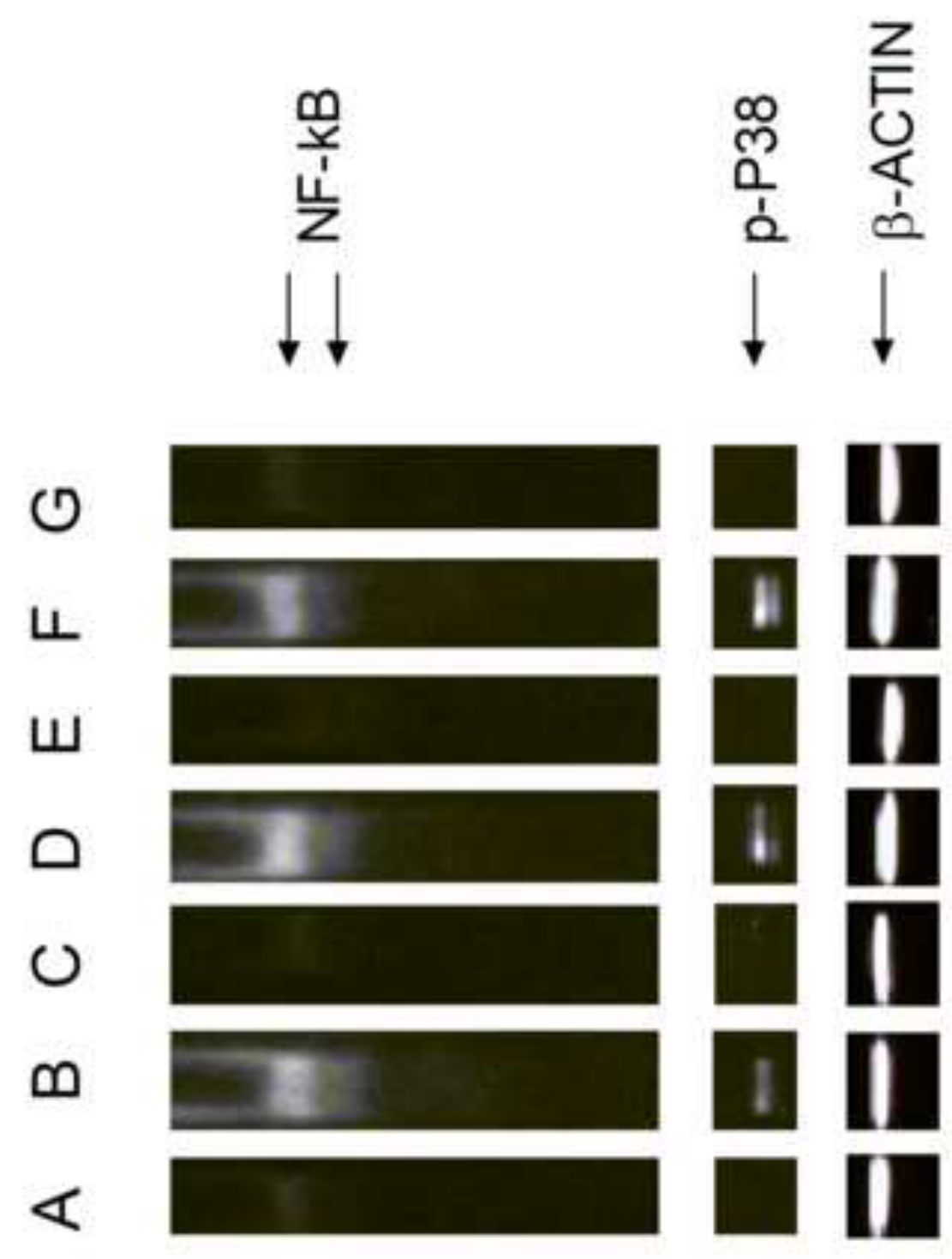




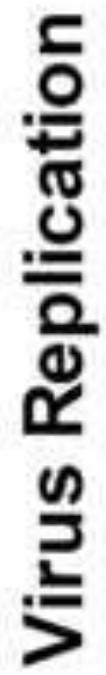

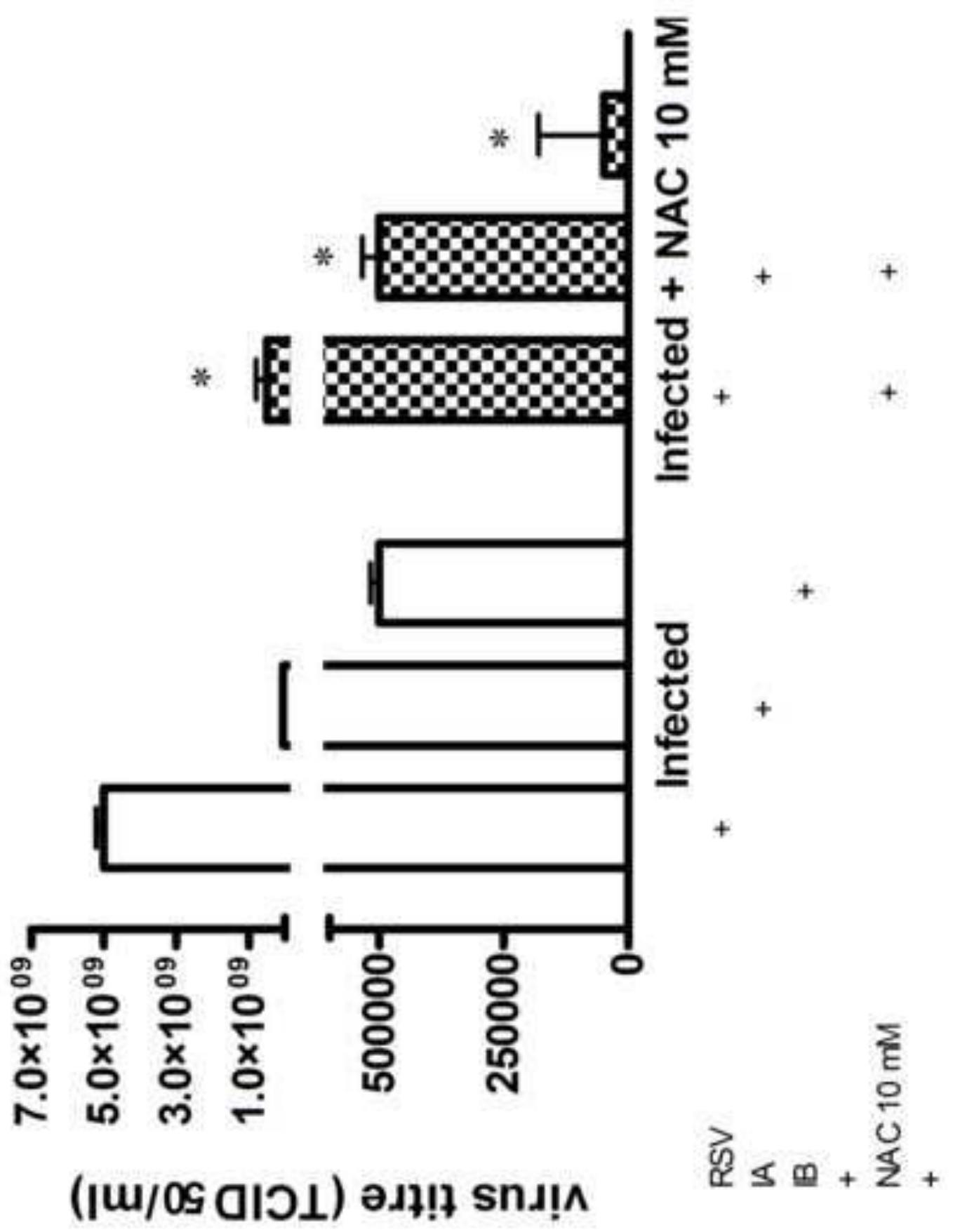

